\begin{tabular}{|l|l|l||}
\hline \multicolumn{2}{|c|}{ PublisherInfo } \\
\hline \hline PublisherName & $:$ & BioMed Central \\
\hline \hline PublisherLocation & $:$ & London \\
\hline \hline PublisherImprintName & $:$ & BioMed Central \\
\hline \hline
\end{tabular}

\title{
Juicy transgenics
}

\begin{tabular}{|l|l|l||}
\hline \multicolumn{2}{|c|}{ ArticleInfo } \\
\hline \hline ArticleID & $:$ & 4022 \\
\hline \hline ArticleDOI & $:$ & $10.1186 /$ gb-spotlight-20010321-01 \\
\hline \hline ArticleCitationID & $:$ & spotlight-20010321-01 \\
\hline \hline ArticleSequenceNumber & $:$ & 93 \\
\hline \hline ArticleCategory & $:$ & Research news \\
\hline \hline ArticleFirstPage & $:$ & 1 \\
\hline \hline ArticleLastPage & $:$ & 2 \\
\hline \hline & & RegistrationDate : 2001-03-21 \\
ArticleHistory & $:$ & OnlineDate $\quad$ 2001-03-21 \\
\hline \hline ArticleCopyright & $:$ & BioMed Central Ltd2001 \\
\hline \hline ArticleGrants & $:$ & \\
\hline \hline ArticleContext & $:$ & 130592211 \\
\hline \hline
\end{tabular}




\section{Jonathan B Weitzman}

Email: jonathanweitzman@hotmail.com

Citrus trees have a long juvenile phase (6-20 years) that delays their reproductive development. In the March Nature Biotechnology, Pena et al. report genetic experiments that accelerated the citrus flowering time (Nature Biotechnology 2001, 19:263-267). They produced transgenic juvenile orange trees that constitutively express Arabidopsis LEAFY (LFY) or APETALA1 (AP1) genes driven by the cauliflower mosaic virus promoter. Both of these flowering genes could shorten the juvenile phase and promote early flowering in the citrus plants. The transgenic flowers were normal and fertile. Furthermore, these traits were inherited in subsequent generations of plants a dominant fashion. Such fruitful results will contribute to the genetic improvement of orange trees and provide good news for citrus lovers.

\section{References}

1. The specification of leaf identity during shoot development.

2. Nature Biotechnology, [http://biotech.nature.com]

3. When to switch to flowering.

This PDF file was created after publication. 